\title{
Study the Influence of Gas Metal Arc Welding Parameters on the Weld Metal and Heat Affected Zone Microstructures of Low Carbon Steel
}

\author{
Tarik Tawfeek \\ Mechanical Engineering Department, Faculty of Engineering, \\ Benha University, Cairo, Egypt \\ tariktewfic@yahoo.co.uk
}

\begin{abstract}
The Heat-Affected Zone (HAZ) is the region of base metal which has its microstructure altered by welding. Microstructural changes affect the composition of the weldment and need to be controlled since the weld failures are directly related to the microstructure of the Heat affected Zone. This paper is focused on the study of the Gas Metal Arc Welding (GMAW) parameters on the Heat Affected and Weld metal Zone microstructures of industrial low carbon steel $(0.20 \% \mathrm{C})$. In order to achieve the aim of the paper, Scan Electron Microscope photos have been used at the Heat Affected and weld metal Zones, some phases are identified. Microstructural analyses of the experimental results of the welded joints confirmed that the welding parameters and heat input are affected the weldment structure in terms of the grain types and character of the structural phase.
\end{abstract}

Keyword-GMAW, HAZ, WM, Wire feed rate, Microstructure.

\section{INTRODUCTION}

Gas Metal Arc Welding (GMAW) process is a relatively complex process, but is widely used in industry because of the speed at which joints can be made and the reliability of these joints in service. Microstructure control is crucial to weld quality and prevention of weld failures. The development of techniques to more effectively control microstructure created during welding will have a significant positive impact on product cost and quality [1]-[4].

In a pass of the welding torch material is rapidly heated to the maximum temperature and allowed to cool more slowly by conduction of heat into the bulk of the parent metal. Phase changes can occur depending on the temperature reached. The region next to the fusion zone where microstructural changes have occurred is known as the heat affected zone. Such microstructural changes may affect the mechanical properties of the weld and need to be controlled (e.g. brittle martensite formation) [5]-[7].

In the welding of steels the chemical composition of the base material is directly affected the final structures and mechanical properties of the welded joint. Carbon percentage play a lead role in the ability of welding, low carbon steels exhibited a good welding ability, since they can be generally welded without special precautions using most of the available processes [8]-[10].

Several studies have been conducted to investigate the mechanical behavior and phase transformation of the welded steel joints. Reference [11] presented the effect of heat input on the microstructure and mechanical properties of the heat affected zone of duplex steel. He studied the effect of the heat input on the microstructural changes and the impact properties. Grain growth mechanism of steel welded joint has been investigated as in [12] it has been noticed that the presence of very large grains close to the fusion line and they are oriented along the directions of the heat flow. The present wok aims to study the effect of Gas Metal Arc Welding parameters( interpass temperatures, welding voltage, wire feed Rate and welding speeds) on the Heat Affected Zone (HAZ) and Weld Metal (WM) microstructures of industrial low carbon steel $(0.23 \% \mathrm{C})$.

\section{EXPERIMENTAL WORK}

\subsection{Material}

The Base Metal used in the experiment was carbon steel (St.52-3N).According to the Egyptian Iron and Steel $\mathrm{Co}[13]$.The chemical compositions of the base metal was $0.23 \mathrm{C} \%, 1.70 \mathrm{Mn} \%, 0.60 \mathrm{Si} \%, 0.045 \mathrm{P} \%, 0.045 \mathrm{~S} \%$ and $0.011 \mathrm{~N} \%$. And the mechanical properties was $610 \mathrm{~N} / \mathrm{mm}^{2}$ Tensile Strength, $460 \mathrm{~N} / \mathrm{mm}^{2}$ Upper Yield Point, $22 \%$ elongation and the Vickers hardness is $190 \mathrm{HV}$.

The wire chemical compositions \%According to the ESAB Welding Handbook [14]. Was 0.10.23 C\%, 1.50 $\mathrm{Mn} \%, 0.85 \mathrm{Si} \%$. And the mechanical properties was $630 \mathrm{~N} / \mathrm{mm}^{2}$ Tensile Strength, $470 \mathrm{~N} / \mathrm{mm}^{2} \mathrm{r}$ Yield stress ,25\% elongation and the Vickers hardness is $200 \mathrm{HV}$. 


\subsection{Preparation of the Welding Joints}

Two plates of size 200x100 mm with thickness $10 \mathrm{~mm}$, each with one of the edges chamfered by machining, were taken together to form a weld pad of size $200 \times 200 \mathrm{~mm}$ with a S-V- groove joint, Fig.1.shows the SingleV- groove weld, butt weld joint (B), and prequalified complete joint penetration (CJP) groove welded joint details. The related steel strips were cut to size using band saw.

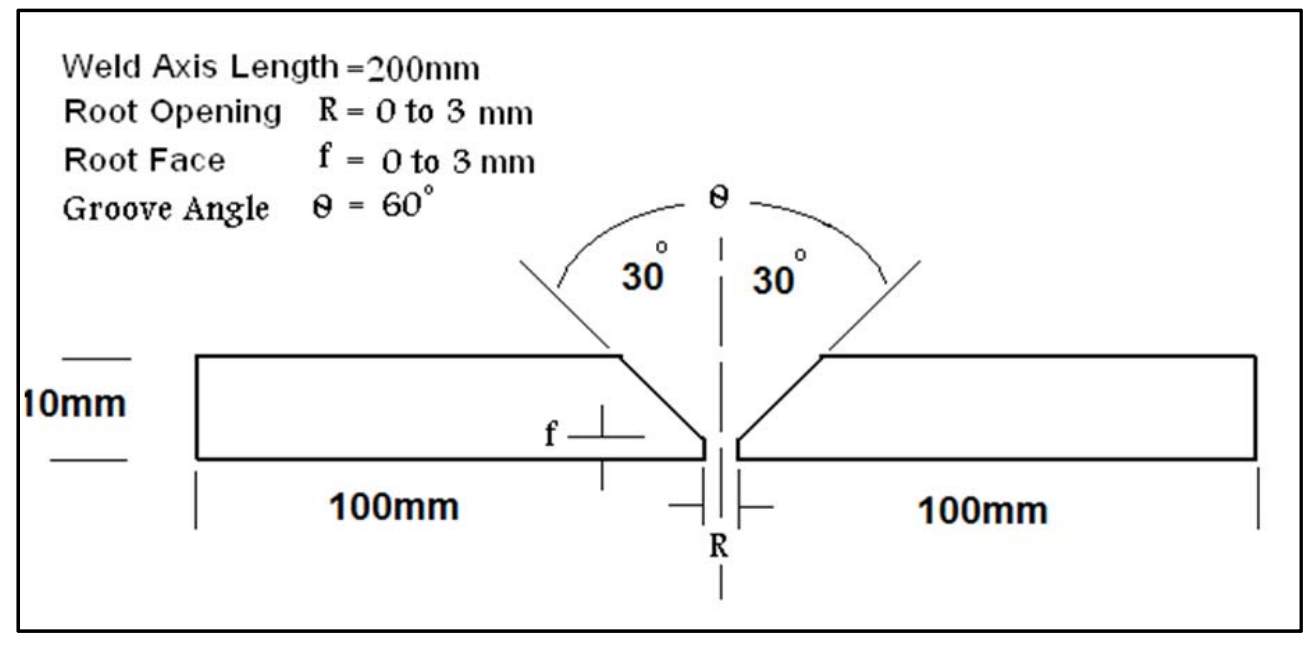

Fig. 1 Welded joint details of S-V-groove butt weld according to AWS code

\subsection{Welding Variables}

Interpass temperature: The interpass temperature is the temperature immediately before each weld run after the first is deposited. The interpass temperatures were varied in the present work between 50 and $500{ }^{\circ} \mathrm{C}$.

Welding Power: The variation in the welding power was produced by the consumed voltage and current during the welding process. The welding powers were varied in the present work between 2.6 to $9.9 \mathrm{k} \mathrm{W}$.

Welding Speed: The welding speed or the travel speed of the welding arc is a function in the wire feed rate of the GMAW machine. The wire feed rate ranges affect on the arc speed directly and were varied in the present work between 3 to $9 \mathrm{~mm} / \mathrm{sec}$.

\subsection{Temperature Measurement Technique}

The welding thermal cycles were recorded with a computer based data acquisition system, using five K-type thermocouples calibrated with certification come from EAST company $(2.5 \mathrm{~mm}$ in diameter, NickelChromium, grade from -200 to $1250^{\circ} \mathrm{C}$, standard error $\pm 2.2^{\circ} \mathrm{C}$ above $0^{\circ} \mathrm{C}$, and thermoelectric voltage $0: 10$ mill volts). The thermocouples are used to measure the temperature distribution during welding. The thermocouples were fixed in the plate to measure the temperature in the two-dimension ( $x-y$ plane) The temperature were measured at distances $12,19.5$, and $27 \mathrm{~mm}$ from the weld centerline on one side plate only at the center plate, for the sensor numbers 4,3 , and 2 respectively. And $12 \mathrm{~mm}$ from the weld centerline for the sensor numbers 1 , and 5 at the two edges of the plat at the top surface of the test plate.

The NI CFP- TC120 module built-in signal compensation (data logger or data acquisition) includes eight differential inputs for thermocouples, resolution of 16 bits resolution for high-accuracy measurements, sample rate $1000 \mathrm{sample} / \mathrm{sec}$, and analog to digital conversion. It also provides cold -junction compensation using a thermistor embedded in the connector block. Details in author previous publication [15].

\subsection{MICROSTRUCTURE EXAMINATIONS}

The first step of preparing the samples for SEM was cutting the samples from the base Metal, WM and HAZ zones to the right size and this has been done by means of rotating saw with fine blades. Next step was applying Planar grinding with a typical abrasive grinding procedure, Starting from course grit of size 120 grit SiC paper followed by decreasing the size of the $\mathrm{SiC}$ paper 400 grit. Finishing with 1000 grit. This is followed by Finer polishing with MICROPAD-NAPPED-high nap polishing pads has been used. Its provides a very soft and gentle polishing action and finally etching with chemical etching (nital)(100ml ethanol and $1 / 10 \mathrm{ml}$ nitric acid), it will remove the very fine grooves along the boundary that will be visible under the microscope and generate a fresh surface for clear SEM examination. 


\section{III.Results}

The microstructure of parent material is shown in Fig. 2,Fine ferrite (light), perlite (dark) structure of low carbon steel is visible, pearlite cells are far less than ferrite.

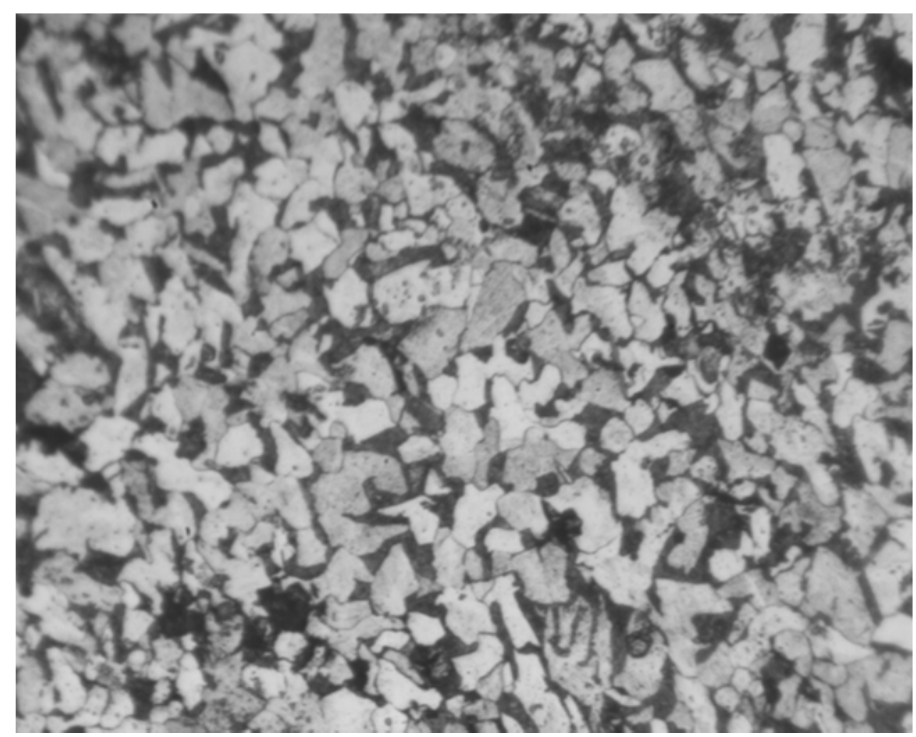

Fig. 2.The microstructure of parent metal

Microstructure of Heat Affected Zone (HAZ) for different wire feed rate are shown in Fig.3.Increasing the wire feed has altered the grains of ferrite and pearlite. Wire feed $7 \mathrm{~m} / \mathrm{min}$ has brought about some dendritic coaxial grain. As depicted in the following Fig.

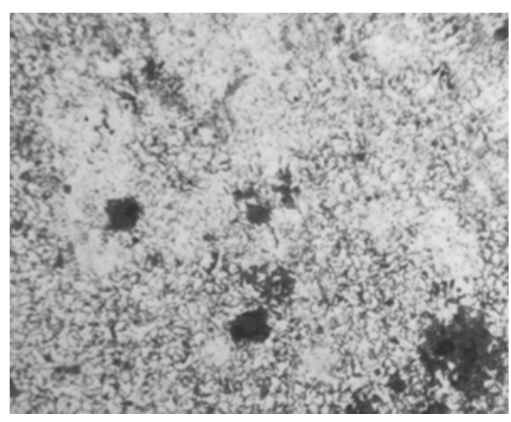

A

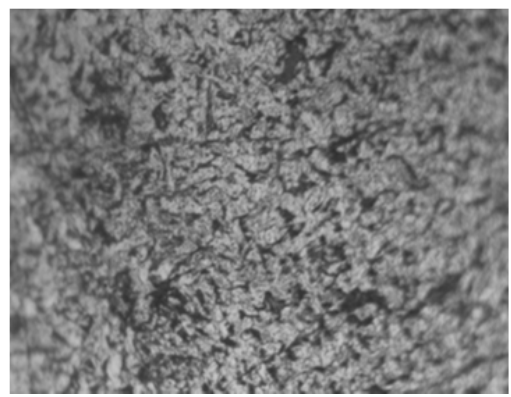

$\mathrm{D}$

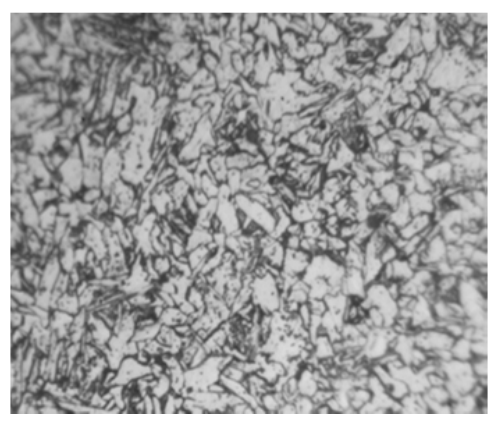

B

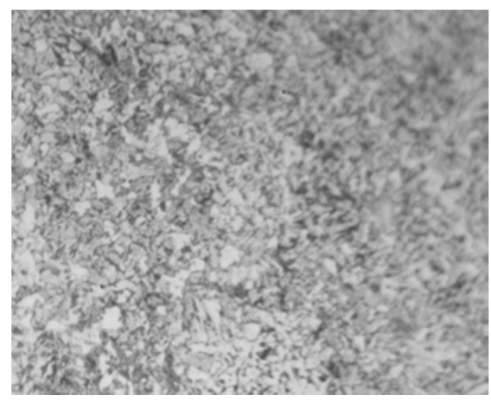

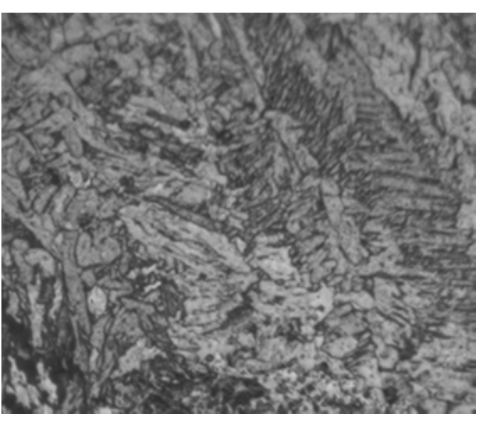

$\mathrm{C}$

Wire feed rate

A:3 $\mathrm{m} / \mathrm{min}$

$\mathrm{B}: 5 \mathrm{~m} / \mathrm{min}$

$\mathrm{C}: 7 \mathrm{~m} / \mathrm{min}$

$\mathrm{D}: 9 \mathrm{~m} / \mathrm{min}$

$\mathrm{E}: 11 \mathrm{~m} / \mathrm{min}$

$\mathrm{E}$

Fig.3. Microstructure of Heat Affected Zone (HAZ) for different wire feed rate

Increasing the wire feed is bringing homogeneity to the structure in Weld Metal (WM) zone, wire feed rate 7 $\mathrm{m} / \mathrm{min}$ exhibits the optimum structure. A further increase is resulting in dense grains as shown in Fig.4. 


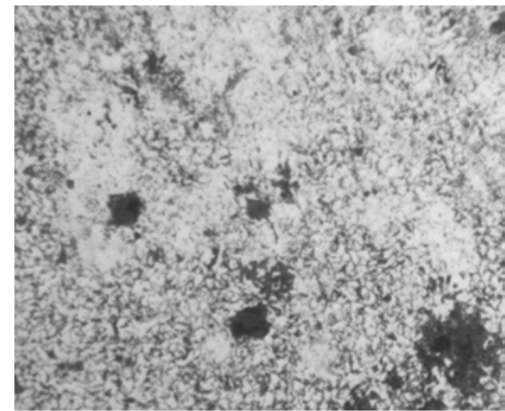

A

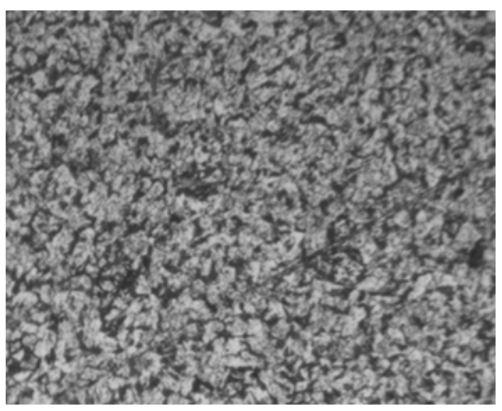

D

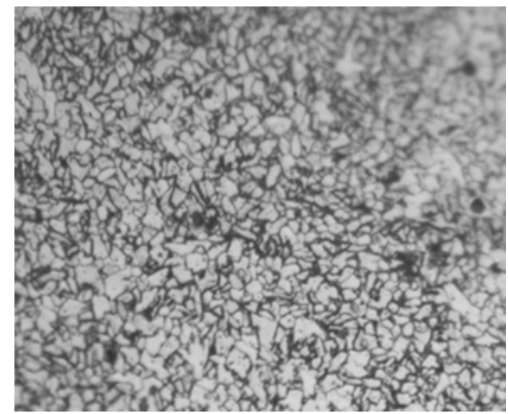

B

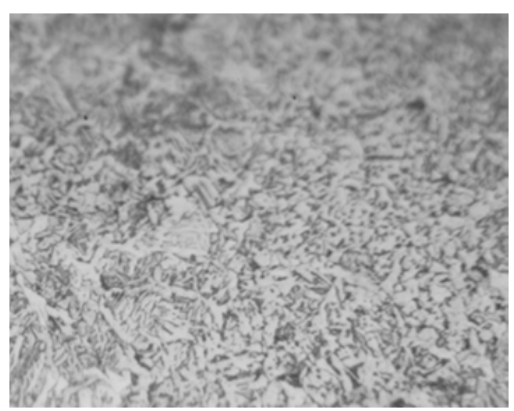

E

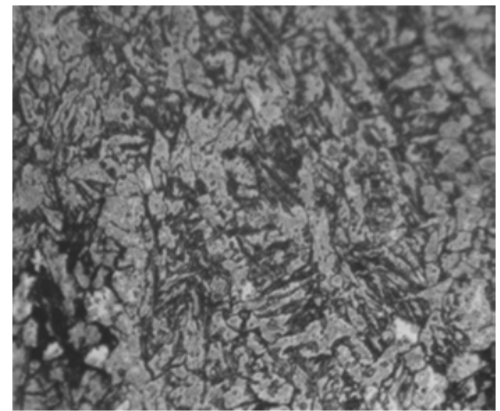

$\mathrm{C}$

Wire feed rate

A:3 $\mathrm{m} / \mathrm{min}$

$\mathrm{B}: 5 \mathrm{~m} / \mathrm{min}$

$\mathrm{C}: 7 \mathrm{~m} / \mathrm{min}$

$\mathrm{D}: 9 \mathrm{~m} / \mathrm{min}$

$\mathrm{E}: 11 \mathrm{~m} / \mathrm{min}$

Fig. 4.Weld Metal zone at different wire feed rate.

Fig.5.represents the microstructure of HAZ under different voltages, with the increase in voltage, the heat input is increasing and hence a visible change in the grain size of ferrite and pearlite are depicted. At a voltage of 35 , dense pearlite structure is visible.

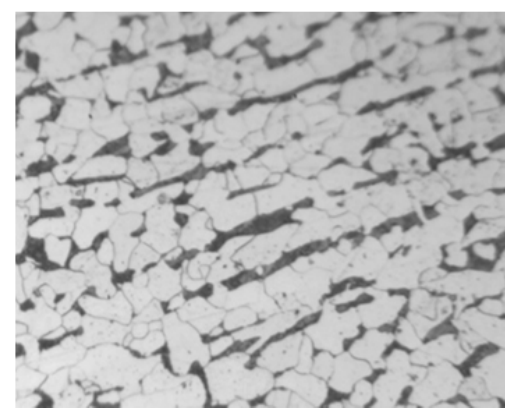

A

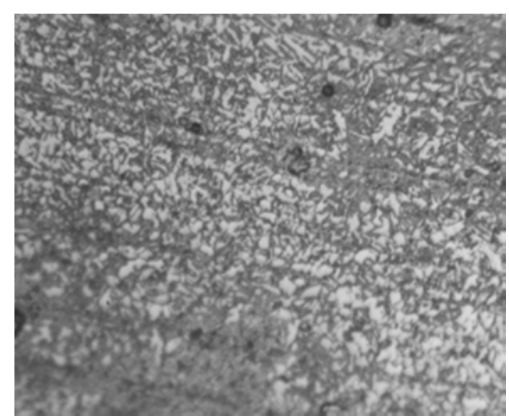

$\mathrm{D}$

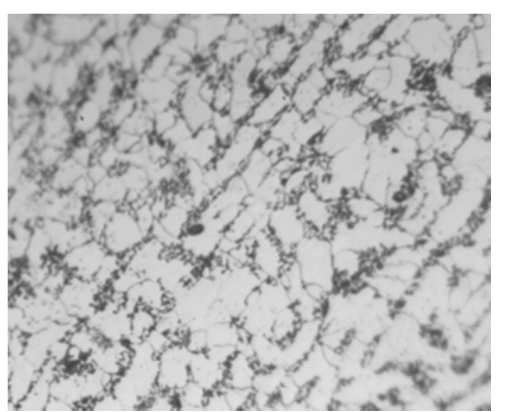

B

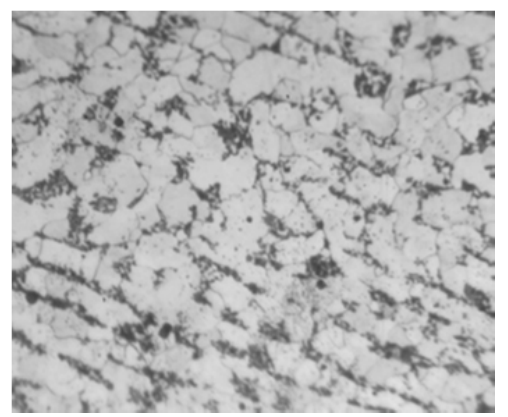

E

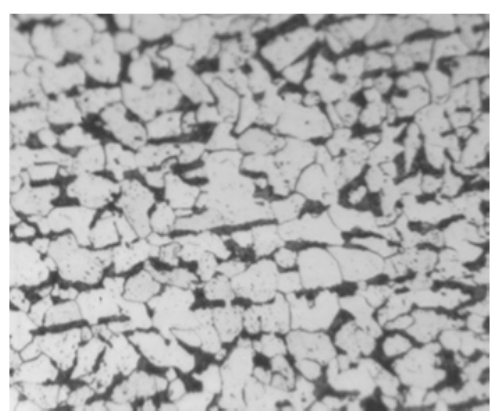

C
Arc Voltage
A:20 volt
B: 25 volt
C:30 volt
D:35volt
E:40volt

Fig.5.Heat effected zone at different voltage and constant wire feed and speed constant.

The grain structure is broken and new recrystallized grains are visible. With voltage of 35 volt the structure is more clear with lamellar layers of ferrite and pearlite grains as illustrated in Fig.6. 


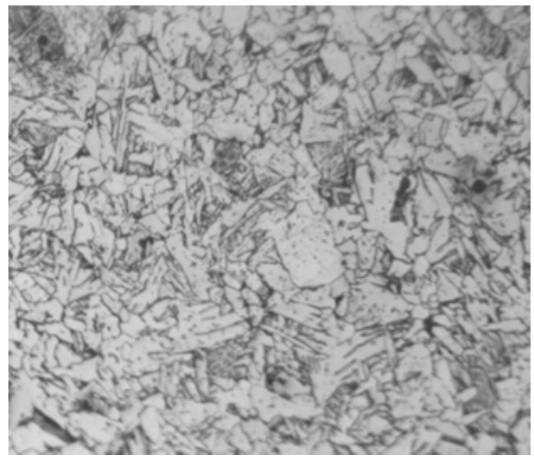

A

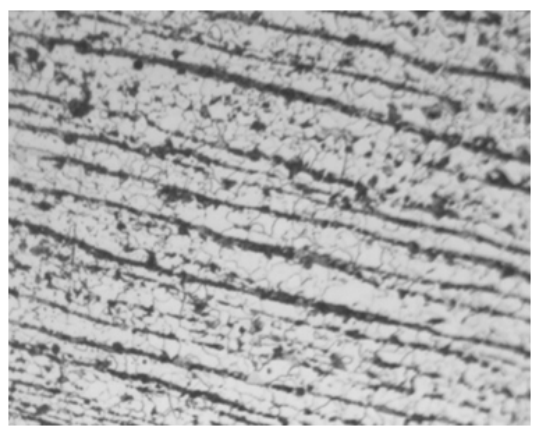

$\mathrm{D}$

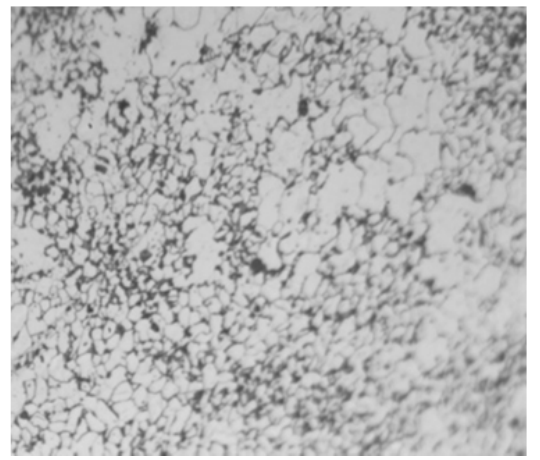

$\mathrm{B}$

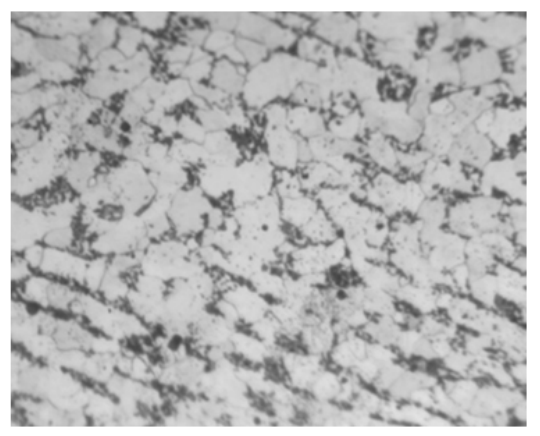

$\mathrm{E}$

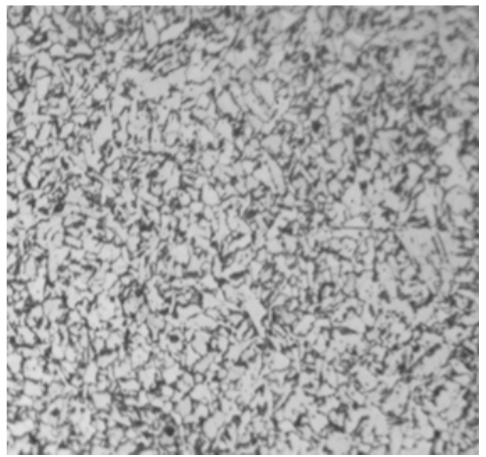

C

Arc Voltage

A:20 volt

B:25 volt

$\mathrm{C}: 30$ volt

D:35volt

E:40volt

Fig. 6.Welding Metal zone varying the voltage $(20,25,30,35 \& 40)$, wire feed and constant speed

At lower speeds there is a marked increase in pearlitic grains. With gradually increasing of the speed, clear grains of ferrite and pearled are visible due to reducing of the heat input. As shown in fig.7.

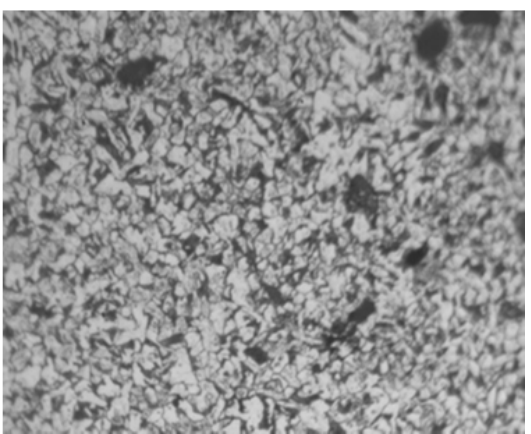

A

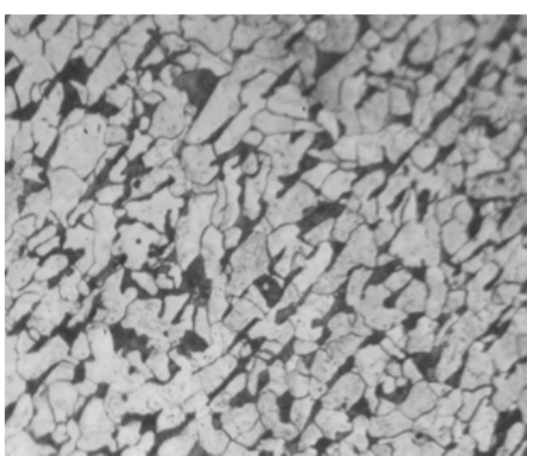

D

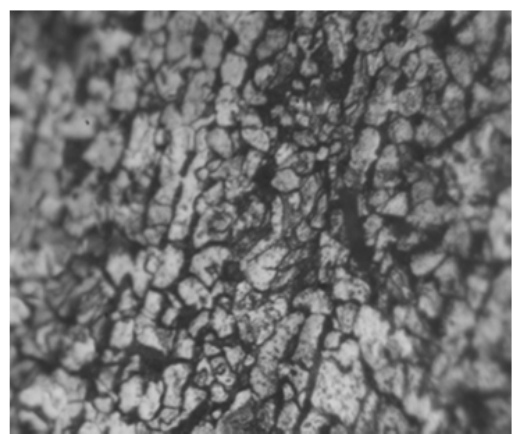

B

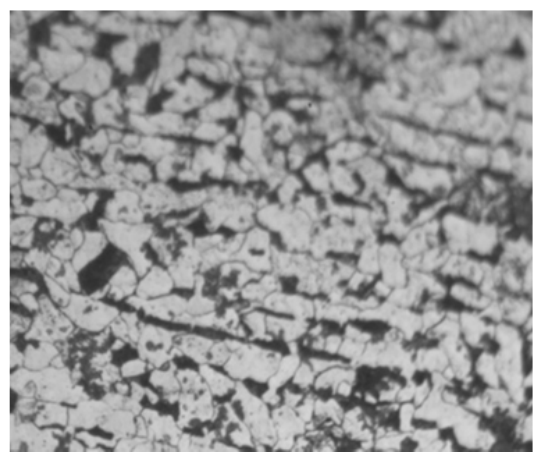

E

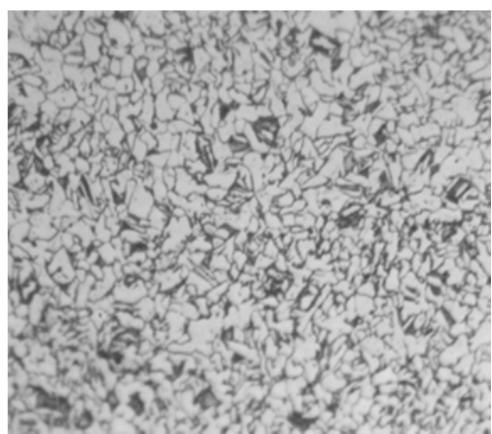

C

Welding Speed

A: $2 \mathrm{~mm} / \mathrm{s}$

B: $4 \mathrm{~mm} / \mathrm{s}$

C: $6 \mathrm{~mm} / \mathrm{s}$

$\mathrm{D}: 8 \mathrm{~mm} / \mathrm{s}$

E: $10 \mathrm{~mm} / \mathrm{s}$

Fig.7. Heat effected zone varying the speed (2,4,6,8\&10), wire feed and constant voltage.

Fig.8. depict the Weld Metal zone as it can be seen from the Fig., at low speeds the grains are clear and as the speed is increasing the dense structure of pearlite and few cementite are visible. 


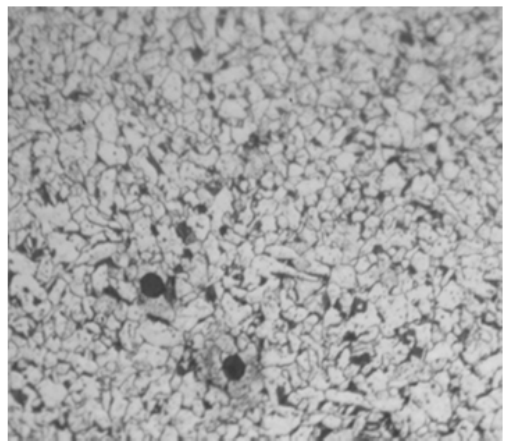

A

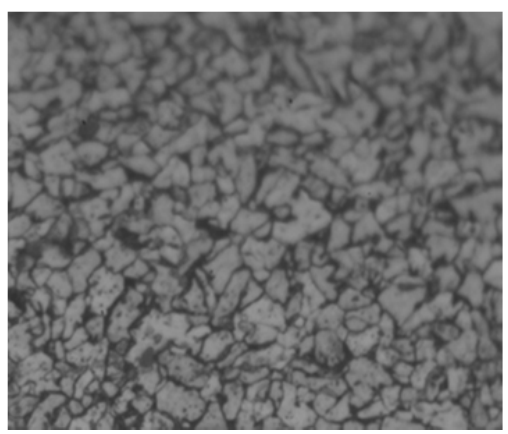

D

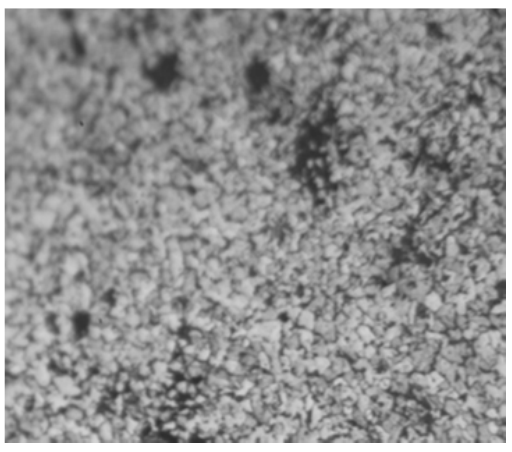

B

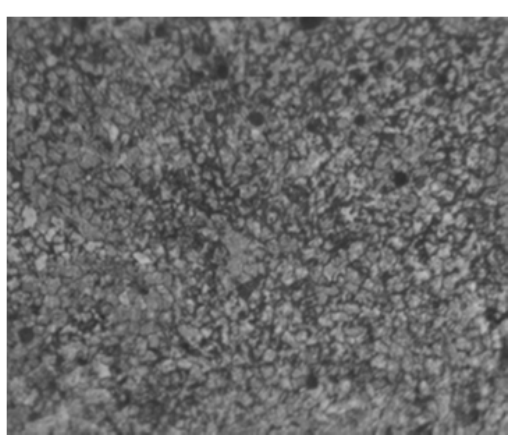

E

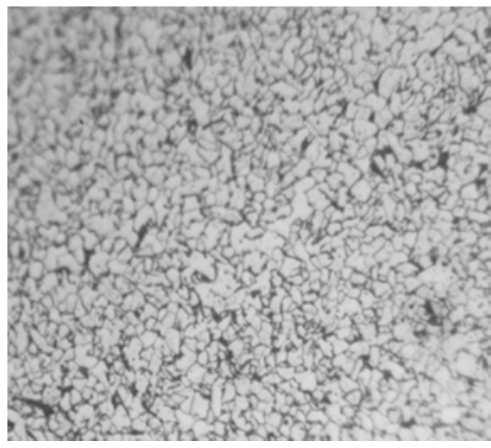

C

\section{Welding Speed}

A: $2 \mathrm{~mm} / \mathrm{s}$

B: $4 \mathrm{~mm} / \mathrm{s}$

$\mathrm{C}: 6 \mathrm{~mm} / \mathrm{s}$

$\mathrm{D}: 8 \mathrm{~mm} / \mathrm{s}$

$\mathrm{E}: 10 \mathrm{~mm} / \mathrm{s}$

Fig.8. Welding effected zone varying the speed (2,4,6,8\&10), wire feed and constant voltage

\section{IV.Discussion}

The heat input is played a lead role of controlling the microstructure and mechanical Properties of GMAW welded joints. It noticed that the lower heat input result in higher cooling rate which develop the coarse grains in weld metal and vice versa.

GMAW parameters can be directly controlling the developed heat input in the HAZ and WM zone. The main welding parameter which has a great effect in the HAZ is the Wire feed rate, as wire feed rate decreases the amount of molten filler on the parent material decreases and consequently the heat input reduces which leads to decreasing the HAZ area due to the higher cooling rate and the microstructure of HAZ consists mainly of massive ferrite with either $\mathrm{Fe}_{3} \mathrm{C}$ or austenite within the ferrite as it can be seen from Fig.3.

The recrystallization started after feed rate of $7 \mathrm{~m} / \mathrm{min}$ with increasing of the wire feed rate the HAZ area increases due to the increasing of the heat input and this leads to lower cooling rate and change on the microstructure of HAZ, the microstructure mainly Ferrite and perlite. Finally it can be concluded that the main parameter which control the size of the HAZ is the wire feed rate [15].

Voltage and welding speed parameters have less effect on the microstructure of HAZ, the structures in Fig.5.revealing that the microstructure of the HAZ under different value of voltage exhibits mainly Widmanstatten Ferrite (WF) and pearlite and this can be due to the medium slow cooling cycle under variable voltage. The welding speed parameter has the less effect on HAZ since the heat input due to the welding speed is smaller compared with wire feed rate an Voltage and this due to the medium high cooling rate. The microstructures exhibit mainly Ferrite and periodic pearlite as it can be seen in Fig. 7.

Wire feed rate and voltage have the great influence in the microstructure of the Weld Metal (WM). Increasing of wire feed rate and voltage increases the depth of bead penetration which leads to increase of the molten metal in WM area hence the heat input increases. While increasing the welding speed decreases the depth of bead penetration. The changes in the heating and cooling cycle of WM result in Acicular ferrite in melting boundary, austenite and cementite according to the applied welding parameters as it can be seen in Figs.4,6,8.

The relatively slow cooling rate due to the effect of high wire feed rate and voltage led to the formation of martensite and acicular ferrite with some retained austenite in weld metal area and this agreed with references[15],[16].Existing of acicular ferrite microstructure leads to higher strength and toughness of the WM than HAZ. The highest value of hardness has been obtained at the center of the weldmetal while it was lowered when measured outside the welded joint area in both sides. It was remarkable the increasing of hardness in both WM and HAZ compared with the parent metal and this can be referred to the diffusion of the large number of carbon atoms in the cementite phase $[15,[17]$. 


\section{CONCLUSONS}

This work was focused on the analysis of the effects of welding process parameters on the Heat Affected Zone (HAZ) and weld metal zone by evaluating microstructure of the welding joint. Base metal of steel grade DIN $17100($ St.52-3N) were welded using the Gas Metal Arc Welding process under different variables.

The analyses of microstructures of the welded joints confirmed that the parameters of welding and the heat input are directly affected the mechanical properties and the microstructure of the welded joint. In general, higher heat input leads to slower cooling rate which results in coarse grains in both HAZ and weld metal while lower heat input leads to fast cooling rate which results in fine microstructure.

Feed Rate and voltage parameters have the great effect on the microstructure of HAZ and WM. While the welding speed has the less effect on the microstructure compared with feed rate and voltage.

\section{REFERENCES}

[1] Bingul Z. and Cook G. E. A real-time prediction model of electrode extension for GMAW. IEEE/ASME Transactions on Mechatronics, 11(1),pp. 47-54, Feb. 2006.

[2] Wang F., Hou W. K., Hu S. J., Kannatey-Asibu E., Schultz W. W., and Wang P. C. Modelling and analysis of metal transfer in gas metal arc welding. Journal of Physics D: Applied Physics, 36, pp. 1143-1152, 2003.

[3] Cao Z., Yang Z., and Chen X. L. Three-dimensional simulation of transient GMA weld pool with free surface. Welding Journal, 83(6), pp. 169-176, Jun. 2004.

[4] Ahmed Faraz, Salman Nisar, Mohammad Amir Khan, Effect of Welding Parameters on the Structural Performance of Fusion Welding Extruded and Injection Molded HDPE Joints. Journal of space technology, Vol-4, No-1,July 2014.

[5] E. Bayaraktar, D. Kaplan, L. Devillers and J. P. Chevalier, "Grain Growth Mechanism during the Welding of Inter-stitial Free (IF) Steels,” Journal of Materials Processing Technology, Vol. 189, No. 1-3, pp. 114-125, 2007.

[6] Zhang W., Roy G. G., Elmer J. W., and DebRoy T., "Modeling of heat transfer and fluid flow during gas tungsten arc spot welding of low carbon steel", American Institute of Physics, Journal of Applied Physics, Vol. 93, pp. 3022-3033, 2003.

[7] A. Gural, B. Bostan and A. T. Ozdemir, "Heat Treatment in Two Phase Region and its Effect on Welding of a Low Carbon Steel," Materials and Design, Vol.28, No. 3, pp. 897-903.2007

[8] Zhang Ying-qiao, Zhang Han-qian, LI Jin-fu, LIU Wei-ming. Effect of heat input on microstructure and toughness of coarse grain heat affected zone in Nb microalloyed HSLA steels. J Iron Steel Research Inter; 16 (5):73e80, 2009.

[9] Eroglu and M. Aksoy, "Effect of Initial Grain Size on Microstructure and Toughness," Materials Science and Engineering A, Vol. 286, No. 2, pp. 289-297, 2000.

[10] E. M. Anawa and A. G. Olabi, "Using Taguchi Method to Optimize Welding Pool of Dissimilar Laser-welded Components," Optics \& Laser Technology, Vol. 40, No. 2, 2008, pp. 379-388.

[11] A. G. Olabi and M. J. S. Hashmi, "The Microstructure and Mechanical Properties of Low Carbon Steel Welded Components after the Application of PWHT," Journal of Material Processing Technology, Vol. 56, No. 1-4, pp. 88-97, 1996.

[12] A.Momeni, H.Arabi, A.Rezaei, H.Badri, SM Abbasi. "Hot deformation behavior of austenite in HSLA-100 microalloyed steel" Mater SciEng A;528:2158e63.2011.

[13] Egyptian Iron \& Steel Co. Hadisolb "Company Profile and product specifications", 2007.

[14] ANSI/AWS "Structural Welding Code-Steel" $16^{\text {th }}$ Edition, American Welding Society, 2005.

[15] A. Hemaid, TarikTawfeek, and O. A. Gaheen, "An Investigation into Effect of Butt Welding Parameters on Weldment Mechanical Properties.” American Journal of Mechanical Engineering, vol. 4, no. 3, pp 92-98, 2016.

[16] Pradip D. Chaudhari1, Nitin N. More2, Effect of Welding Process Parameters on Micro hardness and Microstructure" International Journal of Engineering Research \& Technology (IJERT), Vol. 3 Issue 5, pp 1937-1942, May - 2014.

[17] Anbarasan N, Oyyaravelu R, Kuppan P, "Effect of GMAW process parameters on the influence of bead geometry and HAZ area on ASTM A516 grade 70 Low alloy Pressure vessel steel” International Journal of Techno Chem Research, Vol.01, No.01, pp 01-10, 2015.

\section{AUTHOR PROFILE}

\section{Tarik Mohamed Tawfeek}

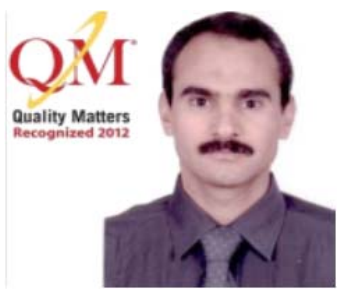

Dr. Tawfeek has a PhD in Design and production engineering, works as lecturer in the faculty of engineering at Benha University, Egypt. He received his $\mathrm{PhD}$ degree from Brunel University in England (2004). He also attended many courses and elearning courses by Quality Matters in USA. Now he is a peer reviewer at the Quality Matters program. Dr. Tawfeek has many research papers published in international journals and conferences. 